\title{
Pattern and Sources of Farm Investment in Agriculture of West Bengal: A Comparative Analysis Between Small and Large
}

\section{Farm}

\author{
Arnab Roy ${ }^{1 *}$, M.N. Venkataramana ${ }^{2}$ and Sreenivasa Murthy D. ${ }^{3}$ \\ ${ }^{1}$ Research Scholar, Department of Agricultural Economics, University of Agricultural Sciences, Bangalore, India \\ ${ }^{2}$ Professor and Head, Department of Agricultural Economics, University of Agricultural Sciences, Bangalore, India \\ ${ }^{3}$ Principal Scientist, ICAR-Indian Institute of Horticultural Research, Bangalore, India
}

"Corresponding author: royarnab_94@rediffmail.com (ORCID ID: 0000-0003-4855-5753)

Received: $10-01-2021$

Revised: 25-02-2021

Accepted: 07-03-2021

\begin{abstract}
The analysis of the farm level investment is a complex problem, being very useful in the planning as well as in policy making process. This paper is the first to attempt a systematic comparison of investment between small and large farms in West Bengal. There has been a growing interest in recent years in the pattern of the capital formation, and sources of farm investment between different categories of farmer. The paper identifies the pattern of investment on different farm assets viz., purchase of land and land improvement, livestock, machinery, farm building, irrigation equipments and perennial crops. Data for the study was generated through a sample survey of 90 farm households from two districts in West Bengal. The rate of capital formation increased as the farm size increased. Purchase of irrigation appliances and land were the major item of capital formation in the farms of both small and large categories. Large farms invested highest on irrigation implements (₹ 66,467) and least on perennial crops (₹ 10,700). However, magnitude of investment was different across the different categories of farm. The per hectare investment on different farm capital assets found higher in case of small farms ( $₹ 2,77,559$ per ha) than large farms (₹ 2,77,010 per ha). On aggregate, share of investment on different items was more than three times higher than investment made by small farmers in the last twelve month on their farms.
\end{abstract}

\section{Highlights}

(0 Per farm investment for large farms were found higher as compare to small farms but the per hectare investment were higher for small farms.

(0 Investment on farm machinery and farm buildings by large farms were 3 times and 2 times higher than small farms, respectively.

Keywords: Farm investment, irrigation equipments, land improvement, perennial crops, capital formation

The role of capital formation has positive impact on agricultural growth as well as poverty alleviation in India. The development in agriculture has remained the major concern of government and policy makers in different plan periods. In this context, Government of India (1998) observed that while the private investment has been the principal source of agricultural growth, particularly in the recent past, and will continue to be so in future, the public investment is essential to correct existing infirmities and to impart added dynamism to this sector. Interestingly lot of debate has been stirred up on the complementary relationship between public and private investment in agriculture. As opined by Chand and Kumar (2004) that there has been a

How to cite this article: Roy, A., Venkataramana, M.N. and Sreenivasa Murthy, D. (2021). Pattern and Sources of Farm Investment in Agriculture of West Bengal: A Comparative Analysis Between Small and Large Farm. Economic Affairs, 66(1): 109-115.

Source of Support: None; Conflict of Interest: None 
AESSRA

Roy et al.

hazy relationship between public investment and its effect on complementary and private investment in the country. Despite the various state and central government assistance in the form of various schemes and subsidies, the farm productivity in India remains very low as Comparison to other countries. Perhaps it may be due to the vicious circle of low productivity in which case it can be inferred that meaningful investment on productive capital assets has not come forth (Venkataramana et al. 2010). Continuous investment on different farm capital assets and replenishment of existing capital assets on farm is indispensable for sustaining agricultural growth as capital assets depreciate continuously due to use and time obsolescence. From the long term development point of view it is extremely useful to assess the pattern of capital formation on the farm level. Investment in terms of private capital formation is generally undertaken by farmer to realize the long term efficiency of existing resources, which, in turn helps farmer to raising the productivity and income earning capacity of existing resources (Saini 2017; Barua et al. 2013; Saini and Kumar, 2020). So it is pertinent to know the investment of different groups of farmers on various long-term assets on the farm. This will give an idea of farmers' priority in the farm development. Hence, the study seeks to address farm level capital formation in West Bengal. This paper tries to analyze the variations of cropping intensity and agricultural output, magnitude of per hectare and per farm investment and sources of capital for investment in West Bengal. In this backdrop, the present study was carried out with the following objectives:

- To assess the pattern of investment in agriculture by farm households.

- To assess the sources of farm investment in agriculture by farm households.

\section{MATERIALS AND METHODOLOGY}

The study was carried out in the two districts which are West Bengal and less-West Bengal in terms of agricultural development of West Bengal state, which presents agriculture, plays a constant and pervasive role in our economy. However, both the districts have almost similar geographical features such as quality of land, topography, soil type, fertility and climatic factors.

\section{Sampling framework}

Data for the study was generated through a sample survey of 90 farm households from two districts comprising 30 small farmers (1-2 ha), 30 medium farmers (2-3 ha), and 30 large farmers ( $>3 \mathrm{ha})$ in West Bengal. The necessary information on capital investment on various assets was collected for the period 2011-12 to 2018-19. Detailed information regarding amount and year of investment, cost of acquisition of assets, expected life span of new farm assets like land, farm buildings, farm machinery and equipment, improvement on land, investment on perennial crops, irrigation structures and equipment and livestock and non-farm household assets like housing, vehicles, cooking gas, electronic goods, furniture, financial assets, etc. was collected. In the present study only gross capital formation was considered.

\section{Analytical techniques}

The actual cost incurred by the respondents in acquiring new capital assets was considered for the study period from 2011-12 to 2018-19. The capital investments made on various assets over the years were expressed at 2019-20 prices by considering the whole sale price index to account for inflationary effects. This is done as given below by dividing the wholesale price index values of $\mathrm{i}^{\text {th }}$ year with the base year price (2008-09) and multiplied by 100.

Index with base year $2019-20=$

$\frac{\text { WPI value of } i^{\text {th }} \text { year }}{\text { WPI value of base year } 2019-20}$

Current values of capital assets (at 2019-20 price) $=$

$\frac{\text { Capital asset value } i^{\text {th }} \text { year }}{\text { Index value of } i^{\text {th }} \text { with base } 2019-20}$

The investments that were included in this study are defined below.

(i) Investment on land and land improvement

(ii) Investment on farm building

(iii) Investment made on farm machinery and equipment

(iv) Investment on irrigation structure and equipment 
(v) Investment on livestock

(vi) Investment on perennial crops

(vii) Investments on non-farm household assets

\section{RESULTS AND DISCUSSION}

Socio-economic status of a farmer's is a measure of social position relative to others which is linked to average standards, material possession, and social participation. Socio-economic status play an important role influence the adoption of recommended farming practices and thereby may have impact on capital formation. Evidence suggest that the farm size, education, age, family size, cropping intensity and area under commercial crops are inherently associated with farming position in terms of income and capital formation. It was observed from the Table 1 that the average farm size for small farms and large farms was found 1.23 ha and 3.90 ha respectively. The overall average farm size was 2.53 ha. The result furnished in the Table 1 showed that the average family sizes were 5.11, 5.31, 5.54 and 5.32 for small, medium, large and all farms respectively. The area under irrigation found highest for large farms (67.02\%) followed by small farms (56.95\%).

Table 1: Socio-economic profile of sample farms in West Bengal

\begin{tabular}{|c|c|c|c|c|}
\hline Particulars & $\begin{array}{l}\text { Small } \\
\text { farms } \\
(\mathrm{n}=30)\end{array}$ & $\begin{array}{l}\text { Medium } \\
\text { farms } \\
(n=30)\end{array}$ & $\begin{array}{l}\text { Large } \\
\text { farms } \\
(\mathrm{n}=30)\end{array}$ & $\begin{array}{l}\text { Pooled } \\
\text { farms } \\
(n=90)\end{array}$ \\
\hline \multicolumn{5}{|c|}{ West Bengal state $(\mathrm{n}=90)$} \\
\hline Farm size (ha) & 1.23 & 2.46 & 3.90 & 2.53 \\
\hline Family size (no.) & 5.11 & 5.31 & 5.54 & 5.32 \\
\hline $\begin{array}{l}\text { Age of respondent } \\
\text { (years) }\end{array}$ & 56.13 & 54.62 & 56.40 & 55.72 \\
\hline Irrigated area (\%) & 56.95 & 65.83 & 67.02 & 63.27 \\
\hline $\begin{array}{l}\text { Area under } \\
\text { commercial crops } \\
(\%)\end{array}$ & 43.09 & 42.28 & 41.03 & 42.13 \\
\hline
\end{tabular}

Nature and type of crops grown predominantly determines the income of farmer. Table 2 presented the existing cropping pattern followed by sample farmers in West Bengal. In West Bengal, the sample farmers grew crops like rice, jute, potato, and mango, pulse (Pal et al. 2017). During kharif season respondents in the study area cultivated rice. Rice occupied an area of 1.08 ha, potato 0.62 ha in the overall cropping pattern in West Bengal state. The cropping intensity was found higher for large farms (165.38\%) followed by medium (163.01\%) and small farms $(160.16 \%)$ in the study area.

Table 2: Cropping pattern of sample farms in West Bengal (ha)

\begin{tabular}{|c|c|c|c|c|}
\hline Crops & $\begin{array}{l}\text { Small } \\
\text { farms } \\
(n=30)\end{array}$ & $\begin{array}{l}\text { Medium } \\
\text { farms } \\
(\mathrm{n}=30)\end{array}$ & $\begin{array}{l}\text { Large } \\
\text { farms } \\
(n=30)\end{array}$ & $\begin{array}{l}\text { Pooled } \\
\text { farms } \\
(n=90)\end{array}$ \\
\hline \multicolumn{5}{|c|}{ West Bengal state $(n=90)$} \\
\hline Rice & 0.54 & 1.07 & 1.63 & 1.08 \\
\hline Potato & 0.30 & 0.75 & 0.81 & 0.62 \\
\hline Jute & 0.42 & 0.83 & 0.85 & 0.70 \\
\hline Vegetables & 0.05 & 0.11 & 0.24 & 0.13 \\
\hline Perennial crops & 0.24 & 0.44 & 1.42 & 0.70 \\
\hline Pulse & 0.31 & 0.60 & 0.75 & 0.55 \\
\hline Oilseed & 0.11 & 0.21 & 0.75 & 0.36 \\
\hline $\begin{array}{l}\text { Gross cropped } \\
\text { area }\end{array}$ & 1.97 & 4.01 & 6.45 & 4.14 \\
\hline $\begin{array}{l}\text { Net cropped } \\
\text { area }\end{array}$ & 1.23 & 2.46 & 3.90 & 2.53 \\
\hline $\begin{array}{l}\text { Cropping } \\
\text { intensity (\%) }\end{array}$ & 160.16 & 163.01 & 165.38 & 162.85 \\
\hline
\end{tabular}

Analysis of cropping intensity in eastern India consistent with the finding of number of researchers (Singh et al. 2018). This result also supports the findings of Nayak et al. (2019) that cropping intensity has positive impact on crop diversification.

\section{Annual income of respondents in West Bengal}

Crop diversification may require more investment in land, seeds, implements, etc., and higher investment depends on higher income. Table 3 represents the annual income from different sources of different categories of farm in West Bengal. There is a striking difference between the level of income from farming and non-farming of small and large farms. Remarkable difference between incomes also found in between different sources of income. Table 3 also revealed that income of small farms from field crops (₹ $1,09,701$ ) were found three times lower than large farms (₹ 3,13,503). Average annual income was ₹ 838075 per household for pooled farmers. Average annual income was highest on large farms with ₹ $12,08,426$ followed by medium farms (₹ 883047) and small farms (₹ 4,22,751). The main source of farm income among pooled farms was livestock sectors which constitute 29.41 per cent of total farm income followed by field crops enterprises (25.82 \%) while 
Table 3: Sources of annual income of farm households in West Bengal (₹/ farm)

\begin{tabular}{|c|c|c|c|c|c|c|c|c|}
\hline Sources & $\begin{array}{l}\text { Small farms } \\
(n=30)\end{array}$ & $\%$ & $\begin{array}{l}\text { Medium farms } \\
(\mathrm{n}=30)\end{array}$ & $\%$ & $\begin{array}{l}\text { Large farms } \\
(n=30)\end{array}$ & $\%$ & $\begin{array}{l}\text { Overall } \\
(n=90)\end{array}$ & $\%$ \\
\hline \multicolumn{9}{|l|}{ (A) Total farm income } \\
\hline 2. Horticultural crops & 44211 & 10.46 & 74790 & 8.47 & 151908 & 12.54 & 90303 & 10.49 \\
\hline 3. Livestock enterprises & 121352 & 28.71 & 271946 & 30.80 & 348118 & 28.73 & 247139 & 29.41 \\
\hline \multicolumn{9}{|c|}{ (B) Total off- farm income } \\
\hline 1. Agricultural labour & 36333 & 8.59 & 9483 & 1.07 & - & - & 15272 & 3.22 \\
\hline \multicolumn{9}{|c|}{ (C) Total non-farm income } \\
\hline 1. Non-agricultural labour & 10250 & 2.42 & 5436 & 0.62 & - & - & 5229 & 1.01 \\
\hline 5. Hiring of machinery & 11557 & 2.73 & 85561 & 9.69 & 144422 & 11.95 & 80513 & 8.12 \\
\hline Sub-total & 111154 & 26.29 & 300423 & 34.02 & 394897 & 32.68 & 268825 & 31.00 \\
\hline Total & $4,22,751$ & 100.00 & 88,3047 & 100.00 & $12,08,426$ & 100.00 & $8,38,075$ & 100.00 \\
\hline
\end{tabular}

Note: Figures in the parentheses indicate percentages to total.

rental income $(8.12 \%)$ and business $(8.15 \%)$ was the major source of non-income. Large farm generates its major part of income from farming enterprise (₹ 8,13,529) followed by non-farm enterprise (₹ 3,94,897). Farm incomes represent 65.11 per cent and 67.13 per cent of the total income of small and large farms respectively while non-farm incomes only represent 26.29 per cent and 32.68 per cent of the total income of small and large farms respectively. Small farms $(8.59 \%)$ have a more share in off-farm income compared to medium farms $(1.07 \%)$.

The share of annual farm income from livestock enterprise was higher among medium farms $(31.74 \%)$ as compare to large farms $(28.73 \%)$ and small farms (28.71\%) whereas share of annual farm income from horticultural sector was higher among large farms (12.54\%) per household as compare to small farms $(10.46 \%)$ in West Bengal. It can therefore be inferred that, large farms with higher income generating activities are more expected to have higher savings capacity than small farms. Similar findings were also found in the studies of Nayak et al. (2020).

\section{Pattern of private investment in West Bengal}

In this section, the investment made on several capital assets by the farmer during the period 2011-12 to 2018-19 at 2019-20 prices was taken into account. We categorize the farm investment into six groups viz., purchase of land and land improvements, irrigation equipment, farm buildings, farm machinery, investment on perennial crops, and purchase of livestock.

Pattern of investment on various farm capital assets in West Bengal has presented in Table 4 and Fig.1. Item-wise classification of private sector agricultural investment during 2011-12 to 2018-19 indicated that investment on irrigation structure and equipment's for overall farms enjoyed special status with an investment of ₹ 1,01,572 per hectare, followed by purchase of land and land improvements (₹ .65,670 per hectare), investment on farm machinery (₹ 48,401 per hectare). The total investment on farm by small, medium and large farmers was $₹ 3,41,397$ per farm, ₹ 6,63,924 per farm and $10,80,338$ per farm respectively. Among the respondents, small, medium and large farmers invested more on purchase of land and land improvements i.e. ₹ 70,220 per farm, ₹ 16,5,350 per farm and ₹ 2,83,554 per farm than the farm buildings and irrigation structure and equipment's. Investment on farm buildings and farm machinery by the large farmers was ₹ 62,733 per farm and 
Table 4: Investment pattern on different farm capital assets in West Bengal (Period: 2011-12 to 2018-19 at 2019- 20 prices) (₹)

\begin{tabular}{|c|c|c|c|c|c|c|c|c|c|c|c|c|}
\hline \multirow[t]{2}{*}{ Assets } & \multicolumn{3}{|c|}{$\begin{array}{c}\begin{array}{c}\text { Small farms } \\
(\mathrm{n}=30)\end{array} \\
\text { (Av. area }=1.23 \text { ha.) }\end{array}$} & \multicolumn{3}{|c|}{$\begin{array}{c}\text { Medium farms } \\
(\mathrm{n}=30)\end{array}$} & \multicolumn{3}{|c|}{$\begin{array}{c}\begin{array}{c}\text { Large farms } \\
(\mathrm{n}=30)\end{array} \\
(\text { Av. area }=3.90 \text { ha. })\end{array}$} & \multicolumn{3}{|c|}{$\begin{array}{c}\text { Overall }(\mathrm{n}=90) \\
(\text { Av. area= } 2.30 \text { ha. })\end{array}$} \\
\hline & Per farm & Per ha & $\begin{array}{l}\text { Per } \\
\text { cent }\end{array}$ & $\begin{array}{l}\text { Per } \\
\text { farm }\end{array}$ & Per ha & $\begin{array}{l}\text { Per } \\
\text { cent }\end{array}$ & Per farm & Per ha & $\begin{array}{l}\text { Per } \\
\text { cent }\end{array}$ & $\begin{array}{l}\text { Per } \\
\text { farm }\end{array}$ & Per ha & $\begin{array}{l}\text { Per } \\
\text { cent }\end{array}$ \\
\hline $\begin{array}{l}\text { Purchase of land and } \\
\text { land improvements }\end{array}$ & 70220 & 57090 & 20.57 & 165350 & 67215 & 24.90 & 283554 & 72706 & 26.25 & 173041 & 65670 & 23.91 \\
\hline Farm buildings & 30777 & 25022 & 9.01 & 51700 & 21016 & 7.79 & 62733 & 16085 & 5.81 & 48403 & 20708 & 7.54 \\
\hline $\begin{array}{l}\text { Farm machinery and } \\
\text { equipment }\end{array}$ & 64225 & 52215 & 18.81 & 111755 & 45429 & 16.83 & 182432 & 46777 & 16.89 & 119471 & 48141 & 17.51 \\
\hline Purchase of livestock & 22475 & 18272 & 6.58 & 31675 & 12876 & 4.77 & 83453 & 21398 & 7.72 & 45868 & 17516 & 6.36 \\
\hline $\begin{array}{l}\text { Irrigation structure } \\
\text { and equipment's }\end{array}$ & 143533 & 116694 & 42.04 & 231377 & 94056 & 34.85 & 366467 & 93966 & 33.92 & 247126 & 101572 & 36.94 \\
\hline Perennial crops & 10167 & 8266 & 2.98 & 72067 & 29295 & 10.85 & 101700 & 26077 & 9.41 & 61311 & 21213 & 7.75 \\
\hline Total & $3,41,397$ & $2,77,559$ & 100.00 & $6,63,924$ & $2,69,888$ & 100.00 & $1,08,0338$ & $2,77,010$ & 100.00 & $6,95,220$ & $2,74,819$ & 100.00 \\
\hline
\end{tabular}

Note: Figures in parentheses indicate percentage to the total investment.

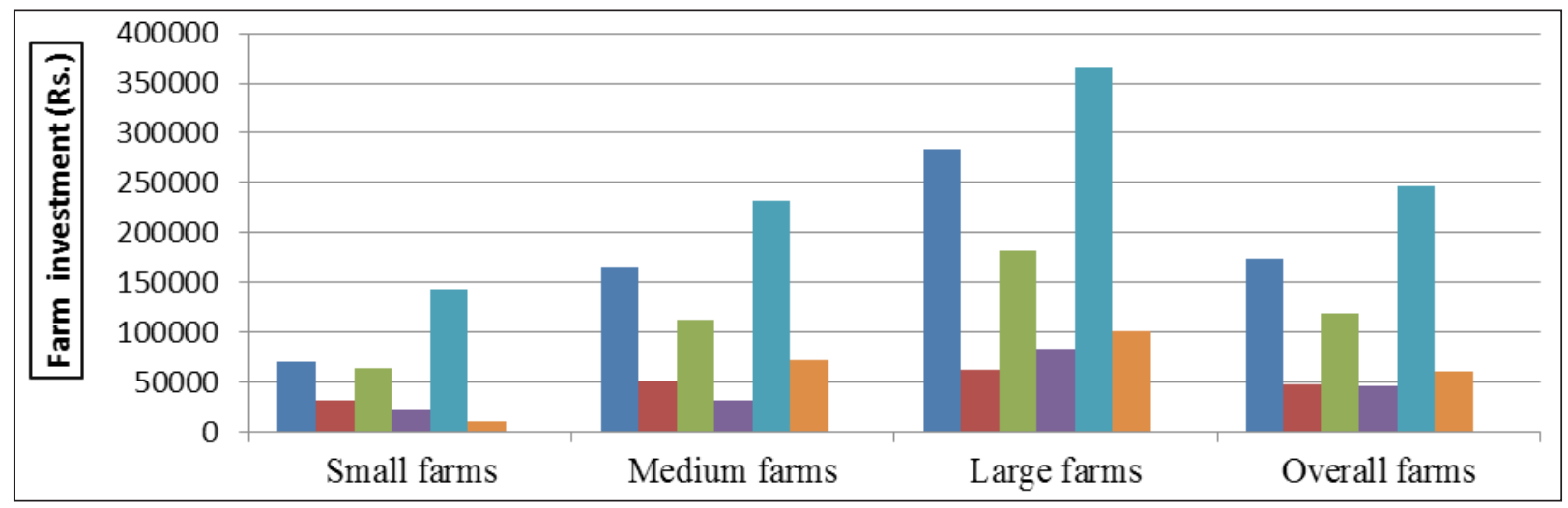

Fig. 1: Investment pattern on different farm capital assets

₹ $1,82,432$ per farm whereas investment on same items by the small farmers was ₹ 30,777 per farm and $₹ 64,225$ per farm. Investment on purchase of livestock and irrigation structure by the small farmers was ₹ 22,475 per farm and ₹ $1,43,553$ per farm whereas investment on same items by the large farmers was ₹ 83,453 per farm and ₹ 3,66,467 per farm.

The proportion of per farm investment small and large farmers investing on farm machinery and equipment was 18.81 per cent and 16.89 per cent respectively whereas per farm investment on irrigation structure and equipment's was 42.04 per cent and 33.92 per cent respectively. Investing irrigation structure and equipment's was another important item of investment where more than
33 per cent of total investment across different categories has invested. Similarly the proportion of per farm investment on perennial crops and purchase of livestock by overall categories of farmers investing was 7.75 per cent and 6.36 per cent respectively. Increase in investment in farm enterprise was found to positively influence adoption behavior and similar conclusions have been drawn elsewhere (Mistri et al. 2015).

The proportion of per farm investment small and large farmers investing on farm buildings was 9.01 per cent and 5.81 per cent respectively whereas per farm investment on land and land improvements was 20.57 per cent and 26.25 per cent respectively. The average figures for all farmers in West Bengal state showed that maximum investment was on 
irrigation structure amounting to ₹ 2,47,126 per farm $(36.94 \%)$. Investment on livestock for all farmers was ₹ 45,868 per farm ( $₹ 17,516$ per ha) and this accounted for more than 6 per cent. Overall, the large farmers had invested 3 times higher amount (₹ 10,80,338 per farm) on different farm capital assets than small farmers ( $₹ 3,41,397$ per farm) in the West Bengal state but the per hectare investment on different farm capital assets found higher in case of small farms than large farms. The per hectare investment on different farm capital assets found higher in case of small farms (₹ 2,77,559 per ha) than medium farms (₹ 2,77,010 per ha). Similar findings were also found in several studies in West Bengal as well as eastern India (Behra et al. 1999; Rehman et al. 2020).

\section{Sources of capital for farm investment in West Bengal}

Detail analysis of sources of finance for capital formation in farm assets through borrowed and owned funds in West Bengal are presented in Table 5. The result of analysis of farm household assets formed through owned and borrowed funds in West Bengal has been summarized in table 5. The farm household assets acquired on pooled farms in progressive state were mainly through owned funds (₹ 5,11,965 per farm; $72.85 \%$ ) as compared to borrowed funds ( $₹ 1,83,255$ per farm; $27.15 \%$ ). Almost all assets formed were created by means of borrowed funds by small farms, which 29.86 per cent of total investment. The large farm families used more of owned funds ( $₹$ 8,07,356 per farm; $74.73 \%$ ) than the small farmer families (₹ 2,39,443 per farm; $70.14 \%)$. The medium farmers used more of their owned funds (₹ 4,89,095 per farm) to the extent of 73.67 per cent of total investment followed by borrowed funds ( $₹ 1,74,828$ per farm) to the extent of 26.33 per cent towards capital formation in West Bengal. In the case of small farmers, borrowed funds were invested largely on farm buildings (34\%) and irrigation structure \& equipments (33.60\%) whereas major assets created using owned funds by small farms were on perennial crops (100\%) and purchase of land $(73.50 \%)$.

In the case of large farmers, borrowed funds were invested largely on farm machinery and equipment $(31.81 \%)$ and irrigation structure \& equipments $(30.55 \%)$ whereas major assets created using owned funds by large farms were on perennial crops (91.45\%), purchase of land $(79.40 \%)$.

Table 5: Agricultural capital assets formation through owned and borrowed funds in West Bengal (Period: 201112 to $2018-19$ at $2019-20$ prices) (₹/Farm)

\begin{tabular}{|c|c|c|c|c|c|c|c|c|c|c|c|c|}
\hline \multirow[t]{2}{*}{ Particulars } & \multicolumn{3}{|c|}{$\begin{array}{l}\text { Small farms }(\mathrm{n}=30) \\
(\text { Av. area= } 1.23 \text { ha.) }\end{array}$} & \multicolumn{3}{|c|}{$\begin{array}{l}\text { Medium farms }(\mathrm{n}=30) \\
(\text { Av. area }=2.46 \text { ha. })\end{array}$} & \multicolumn{3}{|c|}{$\begin{array}{l}\text { Large farms }(n=30) \\
\text { (Av. area }=3.90 \text { ha.) }\end{array}$} & \multicolumn{3}{|c|}{$\begin{array}{c}\text { Overall }(n=90) \\
(\text { Av. area }=2.30 \text { ha. })\end{array}$} \\
\hline & $\mathrm{O}$ & B & Total & $\mathrm{O}$ & B & Total & O & B & Total & $\mathrm{O}$ & B & Total \\
\hline $\begin{array}{l}\text { irchase of } \\
\text { nd and land } \\
\text { provements }\end{array}$ & $\begin{array}{l}51612 \\
(73.50)\end{array}$ & $\begin{array}{l}18608 \\
(26.50)\end{array}$ & $\begin{array}{l}70220 \\
(100.00)\end{array}$ & $\begin{array}{l}124839 \\
(75.50)\end{array}$ & $\begin{array}{l}40511 \\
(24.50)\end{array}$ & $\begin{array}{l}165350 \\
(100.00)\end{array}$ & $\begin{array}{l}225142 \\
(79.40)\end{array}$ & $\begin{array}{l}58412 \\
(20.60)\end{array}$ & $\begin{array}{l}283554 \\
(100.00)\end{array}$ & $\begin{array}{l}133864 \\
(76.13)\end{array}$ & $\begin{array}{l}39177 \\
(23.87)\end{array}$ & $\begin{array}{l}173041 \\
(100.00)\end{array}$ \\
\hline Farm buildings & $\begin{array}{l}20159 \\
(65.50)\end{array}$ & $\begin{array}{l}10618 \\
(34.50)\end{array}$ & $\begin{array}{l}30777 \\
(100.00)\end{array}$ & $\begin{array}{l}36345 \\
(70.30)\end{array}$ & $\begin{array}{l}15355 \\
(29.70)\end{array}$ & $\begin{array}{l}51700 \\
(100.00)\end{array}$ & $\begin{array}{l}44804 \\
(71.42)\end{array}$ & $\begin{array}{l}17929 \\
(28.58)\end{array}$ & $\begin{array}{l}62733 \\
(100.00)\end{array}$ & $\begin{array}{l}33769 \\
(69.07)\end{array}$ & $\begin{array}{l}14634 \\
(30.93)\end{array}$ & $\begin{array}{l}48403 \\
(100.00)\end{array}$ \\
\hline $\begin{array}{l}\text { Farm } \\
\text { machinery and } \\
\text { equipment }\end{array}$ & $\begin{array}{l}45792 \\
(71.30)\end{array}$ & $\begin{array}{l}18433 \\
(28.70)\end{array}$ & $\begin{array}{l}64225 \\
(100.00)\end{array}$ & $\begin{array}{l}85493 \\
(76.50)\end{array}$ & $\begin{array}{l}26262 \\
(23.50)\end{array}$ & $\begin{array}{l}111755 \\
(100.00)\end{array}$ & $\begin{array}{l}124400 \\
(68.19)\end{array}$ & $\begin{array}{l}58031 \\
(31.81)\end{array}$ & $\begin{array}{l}182432 \\
(100.00)\end{array}$ & $\begin{array}{l}85228 \\
(72.00)\end{array}$ & $\begin{array}{l}34242 \\
(28.00)\end{array}$ & $\begin{array}{l}119471 \\
(100.00)\end{array}$ \\
\hline $\begin{array}{l}\text { Purchase of } \\
\text { livestock }\end{array}$ & $\begin{array}{l}16407 \\
(73.00)\end{array}$ & $\begin{array}{l}6068 \\
(27.00)\end{array}$ & $\begin{array}{l}22475 \\
(100.00)\end{array}$ & $\begin{array}{l}22964 \\
(72.50)\end{array}$ & $\begin{array}{l}8711 \\
(27.50)\end{array}$ & $\begin{array}{l}31675 \\
(100.00)\end{array}$ & $\begin{array}{l}65494 \\
(78.48)\end{array}$ & $\begin{array}{l}17959 \\
(21.52)\end{array}$ & $\begin{array}{l}83453 \\
(100.00)\end{array}$ & $\begin{array}{l}34955 \\
(74.66)\end{array}$ & $\begin{array}{l}10913 \\
(25.34)\end{array}$ & $\begin{array}{l}45868 \\
(100.00)\end{array}$ \\
\hline $\begin{array}{l}\text { Irrigation } \\
\text { structure and } \\
\text { equipment's }\end{array}$ & $\begin{array}{l}95306 \\
(66.40)\end{array}$ & $\begin{array}{l}48227 \\
(33.60)\end{array}$ & $\begin{array}{l}143533 \\
(100.00)\end{array}$ & $\begin{array}{l}156179 \\
(67.50)\end{array}$ & $\begin{array}{l}75198 \\
(32.50)\end{array}$ & $\begin{array}{l}231377 \\
(100.00)\end{array}$ & $\begin{array}{l}254511 \\
(69.45)\end{array}$ & $\begin{array}{l}111956 \\
(30.55)\end{array}$ & $\begin{array}{l}366467 \\
(100.00)\end{array}$ & $\begin{array}{l}168666 \\
(67.78)\end{array}$ & $\begin{array}{l}78460 \\
(32.22)\end{array}$ & $\begin{array}{l}247126 \\
(100.00)\end{array}$ \\
\hline Perennial crops & $\begin{array}{l}10167 \\
(100.00)\end{array}$ & & $\begin{array}{l}10167 \\
(100.00)\end{array}$ & $\begin{array}{l}63275 \\
(87.80) \\
\end{array}$ & $\begin{array}{l}8792 \\
(12.20) \\
\end{array}$ & $\begin{array}{l}72067 \\
(100.00) \\
\end{array}$ & $\begin{array}{l}93005 \\
(91.45) \\
\end{array}$ & $\begin{array}{l}8695 \\
(8.55) \\
\end{array}$ & $\begin{array}{l}101700 \\
(100.00) \\
\end{array}$ & $\begin{array}{l}55482 \\
(93.08) \\
\end{array}$ & $\begin{array}{l}5829 \\
(6.92) \\
\end{array}$ & $\begin{array}{l}61311 \\
(100.00) \\
\end{array}$ \\
\hline Total & $\begin{array}{l}239443 \\
(70.14) \\
\end{array}$ & $\begin{array}{l}101954 \\
(29.86)\end{array}$ & $\begin{array}{l}341397 \\
(100.00)\end{array}$ & $\begin{array}{l}489095 \\
(73.67) \\
\end{array}$ & $\begin{array}{l}174828 \\
(26.33) \\
\end{array}$ & $\begin{array}{l}663924 \\
(100.00) \\
\end{array}$ & $\begin{array}{l}807356 \\
(74.73)\end{array}$ & $\begin{array}{l}272983 \\
(25.27)\end{array}$ & $\begin{array}{l}1080338 \\
(100.00)\end{array}$ & $\begin{array}{l}511965 \\
(72.85) \\
\end{array}$ & $\begin{array}{l}183255 \\
(27.15)\end{array}$ & $\begin{array}{l}695220 \\
(100.00)\end{array}$ \\
\hline
\end{tabular}

Note: 1. Figures in parentheses indicate percentage to the respective total; $O=$ Owned, $B=$ Borrowed. 


\section{CONCLUSION}

It is understandable from the study that the share of per farm investment on land and land improvements was almost three times higher than investment on farm building by farmers in the last nine years on their farms. In terms of total value, investment on land and land improvements, farm machinery, farm building and livestock dominated the investment profile of the farmers. The large farm families used more of owned funds than the small farmer families. It can therefore be inferred that, large farms with higher income generating activities have higher investment capacity than small farms. Therefore, private investment in agriculture must be encouraged by providing the necessary support like easy access of credit, subsidy on tube-well, subsidy on electricity etc. Resource poor farmers in less-progressive states cannot invest on costly technology like tractor. In that case group investment should be encouraged.

\section{REFERENCES}

Anonymous. 2018. National Accounts Statistics Sources and Methods. New Delhi: Central Statistical Organisation.

Barua, S., Wason, M., Singh, P. and Padaria, R.N. 2013. Impact Assessment of Tribal Sub Plan (TSP) on Livelihood Security of the Beneficiaries in West Bengal. J. Community Mobili. Sust. Dev., 8(2): 212-217.

Behera, U.K. and Mahapatra, I.C .1999. Income and employment generation of small and marginal farmers through integrated farming systems. Ind. J Agrono., 44(3): 431-439.

Chand, R. and Kumar, P. 2004. Determinates of capital formation and agriculture growth - Some new explorations. Econ. Pol. Weekly, 39(52): 5611- 5616.
Mistri, B. and Majhi, K. 2015. Problems and Prospects of Agriculture in Banagram Mouza, Purba Barddhaman, West Bengal. Ind. J. Spatial Sci., 6(2): 47- 55.

Nayak, C. and Kumar, R.C. 2019. Crop diversification in Odisha: an analysis based on panel data. Agric. Econ. Res. Rev., 32(1): 1-15.

Pal, P.K., Bhutia, Phubu, T., Das, L., Lepcha, N. and Nain M.S. 2017. Livelihood Diversity in Family Farming in Selected Hill Areas of West Bengal, India. J. Community Mobilization and Sust Dev., 12(2): 172-178.

Rahman, F.H., Ghorai, D., Sarkar, S., Kundu, S.S. and Das, S. 2020. Doubling Farmers' Income through Integrated Farming System Approach in Purba Barddhaman District of West Bengal. Curr. J. Appl. Sci. Tech., 39(24): 133-141.

Saini, R. 2017. An economic analysis of investment on Punjab farms. M.Sc. Thesis (Unpub.), Punjab Agric. Univ., Ludhiana.

Saini, R. and Kumar, R. 2020. Determining the Factors Affecting Investment in Punjab Agriculture. Econ. Affairs, 65(4): 511-520.

Singh, K.M., Nasim, A., Sinha, D.K., Singh, R. K. P. and Mishra, R.R. 2018. Diversification and its determinants: a search for an alternative income and agricultural development in eastern India. Int. J. Curr. Microbiol. App. Sci., 7(02): 695-702.

Venkataramana, M.N., Chinnappa Reddy, B.V. 2012. Pattern of farm level capital formation and its impact on the farm production efficiency: An economic analysis in two contrasting regions of Karnataka state, India. International Association of Agricultural Economists, Triennial Conference, Foz do Iguaçu, Brazil, pp. 18-24.

Venkataramana, M.N., Chinnappa Reddy, B.V., Jadhav, V. and Roy, A. 2019. Determents of Capital Formation in Agriculture in the Eastern Dry Zone of Karnataka. Econ. Aff., 63(3): 571-582. 
